\title{
Effect of loop diuretics on cholinergic neurotransmission in human airways in vitro
}

\author{
Geert M Verleden, Jan L Pype, Georges Deneffe, Maurits G Demedts
}

\begin{abstract}
Background - Frusemide can inhibit various indirectly acting bronchoconstrictor stimuli in asthmatic patients. Both frusemide and bumetanide also modulate airway neurotransmission in some species but there are no data on the effect of loop diuretics on neurotransmission in man. An in vitro study was performed in human airways to investigate the possible neuromodulatory action of two loop diuretics, frusemide and bumetanide, and to elucidate whether a cyclooxygenase inhibitor such as indomethacin could modulate the effect of frusemide. The effect of acetazolamide, a carbonic anhydrase inhibitor, was also investigated.
\end{abstract}

Methods - Electrical field stimulation (EFS; $40 \mathrm{~V}, 0.5 \mathrm{~ms}, 0.5-32 \mathrm{~Hz}$ for 15 seconds) in human airways with or without epithelium was used to induce a cholinergic contraction $(n=5$ in all experiments). Indomethacin was present throughout. After obtaining a control frequency-response curve, different concentrations of diuretic were added to the organ bath and another frequencyresponse curve was constructed. To determine whether the effect of the diuretic was prejunctional or postjunctional a cumulative concentrationresponse curve to exogenous acetylcholine (Ach, 0.3 $\mu \mathrm{mol} / 1$ to $10 \mathrm{mmol} / \mathrm{l}$ ) was constructed in the presence of a diuretic (frusemide $1 \mathrm{mmol} / 1$ or bumetanide 0.1 mmol/1) or its vehicle. In some experiments indomethacin was omitted from the organ bath to investigate the possible involvement of cyclooxygenase products. Results - Both frusemide $(10 \mu \mathrm{mol} / 1$ to $1 \mathrm{mmol} / \mathrm{l})$ and bumetanide $(1 \mu \mathrm{mol} / \mathrm{l}$ to $0.1 \mathrm{mmol} / 1$ ) produced a concentrationdependent inhibition of the EFS-induced cholinergic contraction in human airways in vitro but only in epithelium denuded tissues. Frusemide ( $1 \mathrm{mmol} / \mathrm{l})$ produced a maximum inhibition of $46.3 \%$ (SE 9.9\%) at $0.5 \mathrm{~Hz}$ and bumetanide $(0.1 \mathrm{mmol} / 1) 39.6$ $(6.2) \%$ at $0.5 \mathrm{~Hz}$. Without indomethacin in the organ bath the frusemide-induced inhibition was enhanced at 4,8 , and $16 \mathrm{~Hz}$, but bumetanide-induced inhibition was not enhanced at any frequency when indomethacin was omitted. Frusemide ( $1 \mathrm{mmol} / 1)$ and bumetanide (0.1 mmol/1) had no effect on the cumulative concentration-response curve to exogenous Ach $(0.3 \mu \mathrm{mol} / 1$ to $10 \mathrm{mmol} / \mathrm{l})$. Acetazolamide $(100 \mu \mathrm{mol} / 1)$ had no effect on the EFS- induced cholinergic contraction in tissues with or without epithelium.

Conclusions - In human airways in vitro both frusemide and bumetanide produced a concentration-dependent inhibition of the EFS-induced cholinergic contraction. This inhibition is mediated through a prejunctional mechanism. Epithelium removal was necessary to achieve this effect. The mechanism of action of frusemide and bumetanide on airway nerves remains unclear: inhibition of the $\mathrm{Na}-\mathrm{K}-\mathrm{Cl}$ cotransporter is a possibility and, for frusemide, release of endogenous cyclooxygenase products may be involved. Carbonic anhydrase inhibition, on the other hand, is unlikely to be a factor.

(Thorax 1994;49:657-663)

It has recently been shown that frusemide, a loop diuretic, can inhibit various indirectly acting bronchoconstrictor challenges in asthmatic patients, including exercise, ${ }^{\mathrm{I}}$ inhaled allergen, ${ }^{2}$ sodium metabisulphite, ${ }^{3}$ distilled water, ${ }^{4}$ adenosine, ${ }^{5}$ and hypertonic saline. ${ }^{6}$ However, frusemide had no inhibitory effect on methacholine or prostaglandin $F_{2 a}$ induced bronchoconstriction. ${ }^{7-9}$ Although this drug seems to prevent effects of indirect challenges in asthmatics, it is curious that bumetanide, a more potent loop diuretic, causes little or no protection against indirect bronchoconstrictor challenges. Speculation continues, therefore, about the potential mechanisms of action, which may not be related to the diuretic effect of these drugs. ${ }^{10}$

In vitro results point to different sites of action and these have been reviewed recently. ${ }^{10-12}$ The in vitro data have come from tissues of different species including guinea pig, ${ }^{13}$ equine, ${ }^{14}$ and bovine. ${ }^{15}$ Only a few experiments have been performed on human tissue, and no data are available on the possible effects of loop diuretics on neurotransmission in human airways in vitro.

We performed this study to assess the effects of frusemide and bumetanide on the cholinergic neurotransmission in human airways in vitro. We also investigated the effect of acetazolamide, a carbonic anhydrase inhibitor, on cholinergic neurotransmission as frusemide, but not bumetanide, possesses an inhibitory effect on carbonic anhydrase. ${ }^{16}$ Electrical field stimulation (EFS) was used to release acetyIcholine (Ach) from postjunctional nerves in human airways and the contractile response to exogenous Ach was measured to evaluate a possible neuromodulatory effect. 


\section{Methods}

\section{TISSUE PREPARATION}

Human airways were obtained from 35 patients (33 men, two women) of mean age 63.6 (range 43-76) years undergoing pulmonary resection, mostly for bronchial carcinoma. Immediately after surgery the airways were macroscopically dissected in the operating theatre, placed in cold $\left(4^{\circ} \mathrm{C}\right) \mathrm{Krebs}-\mathrm{Henseleit}$ $(\mathrm{KH})$ solution $\left(\mathrm{NaCl} 118, \mathrm{KCl} 5.9, \mathrm{MgSO}_{4}\right.$ $1 \cdot 2, \mathrm{CaCl}_{2} 2 \cdot 5, \mathrm{NaH}_{2} \mathrm{PO}_{4} 1 \cdot 2, \mathrm{NaHCO}_{3} 25 \cdot 5$, and glucose $5.5 \mathrm{mmol} / \mathrm{l}$ ) and transported to the laboratory. The airways were carefully stripped from surrounding lung tissue and cut into strips (main bronchi) or ring segments (segmental and subsegmental bronchi) which were mounted between two platinum wire electrodes in $10 \mathrm{ml}$ organ baths containing $\mathrm{KH}$ solution at $37^{\circ} \mathrm{C}$ and continuously bubbled with $95 \%$ oxygen and $5 \%$ carbon dioxide. Indomethacin $(10 \mu \mathrm{mol} / \mathrm{l})$ was present in the organ bath throughout the experiment to block the formation of prostaglandins which may interfere with neutrotransmission. ${ }^{17}$ In a different series of experiments indomethacin was omitted from the organ bath to investigate the possible involvement of cyclooxygenase products.

In most experiments the epithelium was removed by gently rubbing the luminal surface of the bronchi for two minutes with a cotton wool applicator. Complete removal of the epithelium was checked by light microscopy by an experienced pathologist in a blind fashion.

Bronchial strips or rings were connected via silk threads to Grass FT.03 force displacement transducers (Grass Instruments, Quincy, Massachusetts, USA) to measure isometric changes in tension. The tissues were allowed to equilibrate for one hour whilst being washed with fresh $\mathrm{KH}$ solution every 20 minutes under a resting tension of $2 g$, which was found to be optimal for measuring changes in tension. ${ }^{18}$ EFS was produced by a Harvard student stimulator (Harvard, Kent, UK). Biphasic square wave pulses of a supramaximal voltage of $40 \mathrm{~V}$ at source and a pulse duration of $0.5 \mathrm{~ms}$ were applied for 15 seconds every four minutes at frequencies ranging from 0.5 to $32 \mathrm{~Hz}$. Isometric contractile responses were visualised on a computer screen after digitalisation of the signal (Codas, Dataq Instruments, Ohio, USA) and recorded on a personal computer.

\section{PROTOCOI}

\section{Electrical field stimulation}

In human airways EFS causes a rapid contraction that can be abolished by pretreatment of the tissue with atropine, confirming that the contractile response is due to Ach release. After a one hour period of equilibration a frequency-response curve was constructed and discarded. After washing the tissues a control frequency-response curve was performed after which a diuretic or its vehicle (in a separate tissue) was added to the organ bath. The diuretics were incubated for 10 minutes which gives a maximal inhibitory effect. Only one concentration of diuretic was added per tissue. After 10 minutes incubation a third frequency-response curve was performed. The responses to EFS in vehicle-treated tissues were stable throughout the period of the experiment. Six tissues were simultaneously studied with at least one time control tissue per experiment. The responses to EFS were completely blocked by tetrodotoxin $(1 \mu \mathrm{mol} / \mathrm{l})$, confirming their neuronal origin.

\section{Acetylcholine concentration-response curve}

The effect of frusemide ( $1 \mathrm{mmol} / \mathrm{l})$ or bumetanide $(100 \mu \mathrm{mol} / \mathrm{l})$ on a cumulative concentration-response curve to exogenous Ach $(0.3 \mu \mathrm{mol} / 1$ to $10 \mathrm{mmol} / \mathrm{l})$ was studied in human bronchi after a 10 minute incubation period. The results were expressed as a percentage of the maximum contractile response to Ach $(10 \mathrm{mmol} / \mathrm{l})$ which was determined at the beginning of the experiment.

\section{DRUGS}

The drugs used in these experiments were obtained from the Sigma Chemical Co (Eupen, Belgium). Stock solutions of frusemide were made up in $100 \mu \mathrm{mol} / 1$ sodium hydroxide and further diluted with distilled water. Stock solutions of bumetanide were made up in $100 \%$ ethanol and further diluted with ethanol to the appropriate concentration. Acetazolamide was dissolved in $100 \mu \mathrm{mol} / 1$ sodium hydroxide and further diluted with distilled water. All control responses were obtained in the presence of an equivalent amount of solvent. Indomethacin was made up in alkaline phosphate buffer $\left(\mathrm{KH}_{2} \mathrm{PO}_{4} \quad 20 \mathrm{mmol} / \mathrm{l}\right.$, $\mathrm{Na}_{2} \mathrm{HPO}_{4} 120 \mathrm{mmol} / \mathrm{l} ; \mathrm{pH} \mathrm{7 \cdot 8)}$. Fresh drug solutions were made up daily. Drug additions did not exceed $1 \%$ of the bath volume. All concentrations refer to the final organ bath concentrations.

\section{ANALYSIS OF RESULTS}

All contractile responses were measured as the difference between peak tension and the resting tension that developed. The effect of the diuretic was expressed as percentage inhibition, comparing the contractile responses at each frequency after pretreatment with the diuretic with the contraction at the same frequency in the control response. Since each tissue acted as its own control analysis of data was possible using a Student's $t$ test for paired data. Contractile responses to exogenous Ach were compared between diuretic-treated and vehicle-treated tissues by the Student's $t$ test for unpaired data. Results are expressed as mean (SE), $p$ values of $<0.05$ being considered significant.

\section{Results}

EFS in human airways $(40 \mathrm{~V}, 0.5 \mathrm{~ms}, 0.5$ $32 \mathrm{~Hz}$ for 15 seconds) resulted in a rapid cholinergic contraction which increased with increasing frequencies of stimulation. A typical trace, which also demonstrated the inhibitory effect of frusemide, is shown in fig 1 . The 

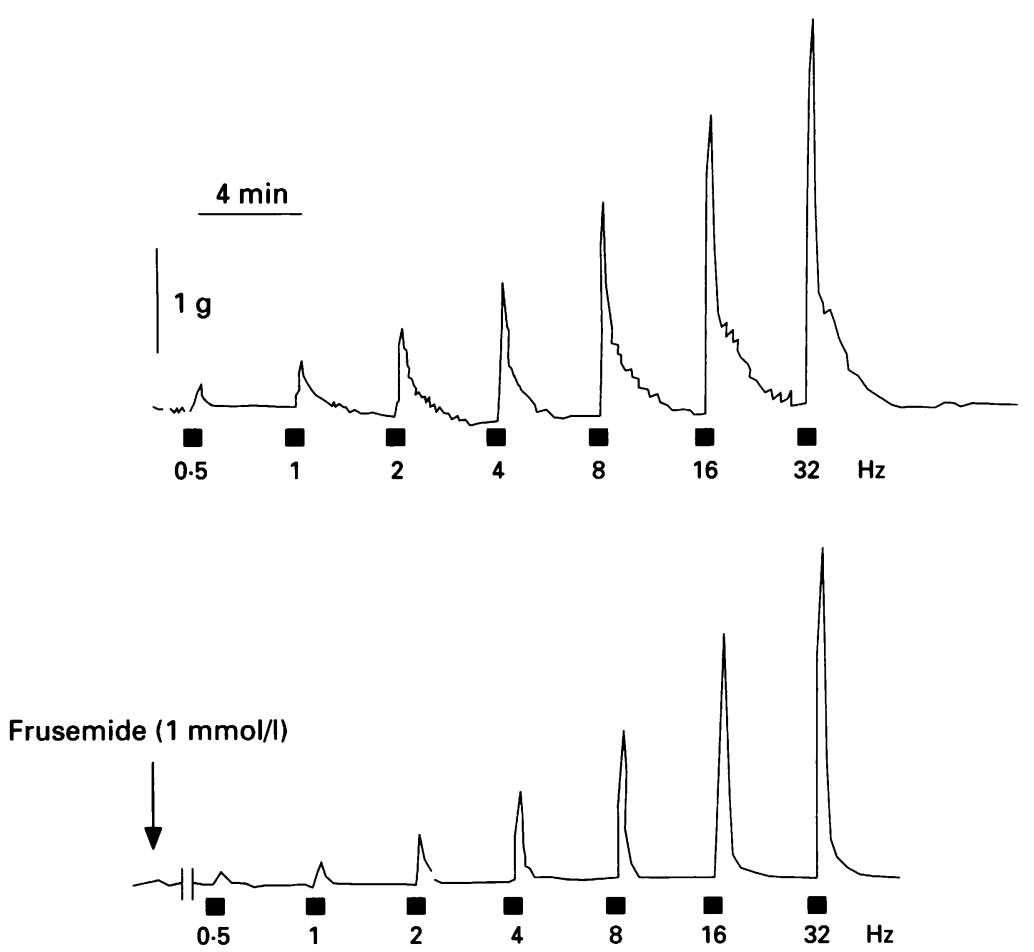

Figure 1 Effect of electrical field stimulation (EFS) $(40 \mathrm{~V}, 0.5 \mathrm{~ms}, 0.5-32 \mathrm{~Hz}$ for 15 seconds) in human airways ( $)$. Frusemide $(1 \mathrm{mmol} / \mathrm{l})$ clearly inhibited the cholinergic contraction at all frequencies.

Mean (SE) inhibitory effect of frusemide (100 $\mu \mathrm{mol} / \mathrm{l})$ in absolute measurements ( $\mathrm{mg}$ )

\begin{tabular}{lccl}
\hline $\begin{array}{l}\text { Frequency } \\
(\mathrm{Hz})\end{array}$ & Control & Frusemide & $\%$ inhibition \\
\hline $0 \cdot 5$ & $302(78)$ & $211(58)$ & $30 \cdot 2(5)$ \\
1 & $327(69)$ & $223(51)$ & $31.9(4)$ \\
2 & $463(71)$ & $299(63)$ & $35 \cdot 5(4.6)$ \\
4 & $618(91)$ & $516(73)$ & $16 \cdot 6(2)$ \\
8 & $809(72)$ & $717(89)$ & $12 \cdot 5(2 \cdot 9)$ \\
16 & $1064(99)$ & $986(108)$ & $7 \cdot 4(1 \cdot 1)$ \\
32 & $1358(109)$ & $1238(73)$ & $8 \cdot 8(2 \cdot 1)$ \\
\hline
\end{tabular}

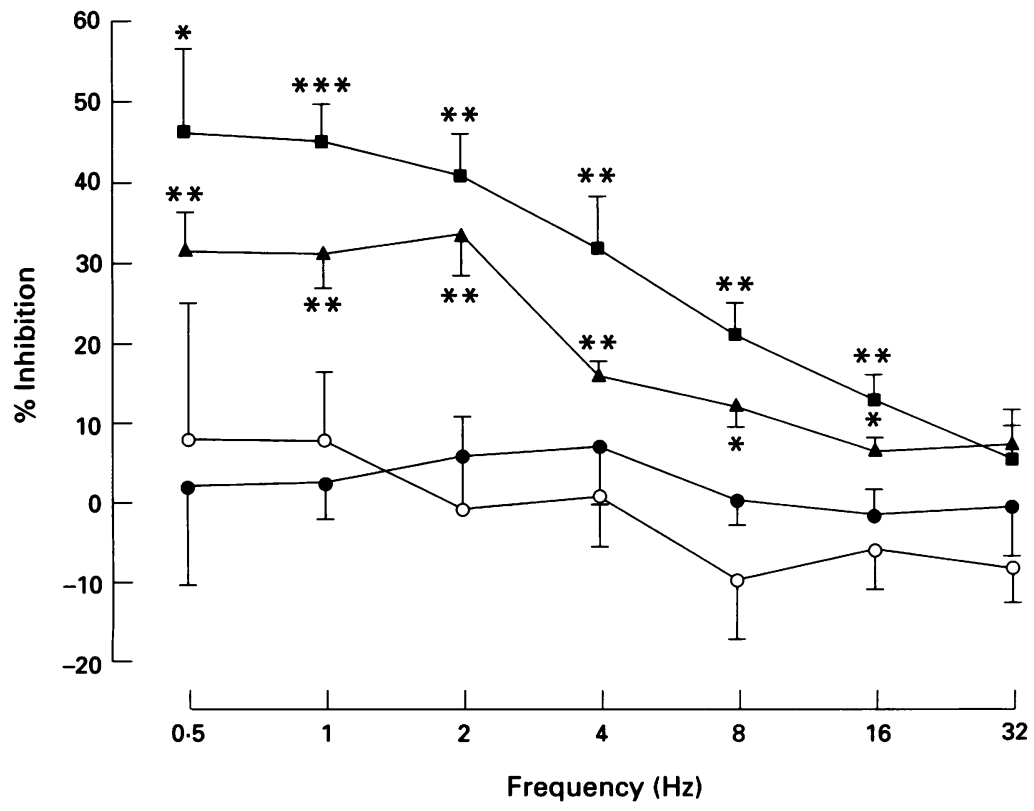

Figure 2 Inhibition of EFS-induced cholinergic contraction by different concentrations of frusemide in human epithelium-denuded airways in the presence of indomethacin $(10 \mu \mathrm{mol} / \mathrm{l}): 0,10 \mu \mathrm{mol} / \mathrm{l}$ frusemide; $\Delta, 100 \mu \mathrm{mol} / \mathrm{l}$ frusemide;, $1 \mathrm{mmol} / \mathrm{l}$ frusemide. The frusemide vehicle ( $O$ ) had no effect on the cholinergic contractions. Means (SE) values of five tissues of different patients are shown. ${ }^{* * *} p<0.001,{ }^{* *} p<0.01,{ }^{*} p<0.05$. inhibitory effect of frusemide $(100 \mu \mathrm{mol} / \mathrm{l})$ in absolute measurements is shown in the table.

\section{EFFECT OF FRUSEMIDE ON CHOLINERGIC}

RESPONSES

In tissues with epithelium frusemide $(1 \mathrm{mmol} /$ 1) produced no inhibition of the cholinergic contractions to EFS, with or without indomethacin $(10 \mu \mathrm{mol} / \mathrm{l})$. When the epithelium was removed and indomethacin $(10 \mu \mathrm{mol} / \mathrm{l})$ was added to the organ bath, frusemide $(100 \mu \mathrm{mol} / 1$ and $1 \mathrm{mmol} / \mathrm{l})$ inhibited the cholinergic contractile responses at all frequencies, which was, however, not significant at $32 \mathrm{~Hz}$. Frusemide $(10 \mu \mathrm{mol} / \mathrm{l})$ had no more significant inhibitory effect on the cholinergic responses. Frusemide $(1 \mathrm{mmol} / \mathrm{l})$ produced a maximum inhibition of $46.3(9.9) \%(n=5$, $\mathrm{p}<0.05)$ at $0.5 \mathrm{~Hz}$ and $45(4.6) \%$ at $1 \mathrm{~Hz}$ stimulation $(n=5, p<0.001)$. There was no significant effect of the vehicle on the cholinergic responses (fig 2).

Without indomethacin in the organ bath frusemide $(10 \mu \mathrm{mol} / \mathrm{l})$ produced no inhibition of the cholinergic responses. The inhibition produced by $100 \mu \mathrm{mol} / 1$ frusemide, however, was significantly enhanced at 4,8 , and $16 \mathrm{~Hz}$ stimulation; at $8 \mathrm{~Hz}$, for example, frusemide $(100 \mu \mathrm{mol} / \mathrm{l})$ produced an inhibition of 12.5 $(2.9) \%$ with indomethacin $(10 \mu \mathrm{mol} / \mathrm{l})$ and $27.4(2.3) \%$ without $(\mathrm{n}=5, \mathrm{p}<0.01)$ (fig 3$)$.

The responses to exogenous Ach $(0.3 \mu \mathrm{mol} / 1$ to $10 \mathrm{mmol} / \mathrm{l}$ ), with or without indomethacin, were not significantly altered by frusemide (1 mmol/l) (fig 4).

\section{EFFECT OF BUMETANIDE ON CHOLINERGIC} RESPONSES

In tissues with epithelium bumetanide $(100 \mu \mathrm{mol} / \mathrm{l})$ had no inhibitory effect on the EFS-induced cholinergic contractions. When the epithelium was removed bumetanide (10 and $100 \mu \mathrm{mol} / \mathrm{l})$ inhibited the cholinergic responses at all frequencies, but not significantly at $16 \mathrm{~Hz}$ and $32 \mathrm{~Hz}$ for $100 \mu \mathrm{mol} / \mathrm{l}$ bumetanide. Bumetanide $(100 \mu \mathrm{mol} / \mathrm{l})$ produced a maximum inhibition of $39.6(6.2) \%$ at $0.5 \mathrm{~Hz}$ $(\mathrm{n}=5, \mathrm{p}<0.01)$ and $38.4(6.6) \%$ at $1 \mathrm{~Hz}$ stimulation $(n=5, p<0.05)$. At $1 \mu \mathrm{mol} / 1$ bumetanide had no significant inhibitory effect on the cholinergic responses, and no significant effect was seen with the vehicle for bumetanide (fig 5).

When indomethacin $(10 \mu \mathrm{mol} / \mathrm{l})$ was omitted the inhibition produced by bumetanide $(10 \mu \mathrm{mol} / \mathrm{l})$ was similar to that produced by the same concentration of bumetanide in the presence of indomethacin $(10 \mu \mathrm{mol} / \mathrm{l})$ (fig 6).

The responses to exogenous Ach $(0.3 \mu \mathrm{mol} / 1$ to $10 \mathrm{mmol} / \mathrm{l}$ ) were not affected by bumetanide (100 $\mu \mathrm{mol} / \mathrm{l}$ ) (fig 7).

\section{EFFECT OF ACETAZOLAMIDE ON CHOLINERGIC} RESPONSES

In tissues with or without epithelium actezolamide $(100 \mu \mathrm{mol} / \mathrm{l})$ produced no significant inhibitory effect $(2 \cdot 2(1 \cdot 5) \%, n=5)$ on the cholinergic responses to EFS in human bronchi (data not shown). 


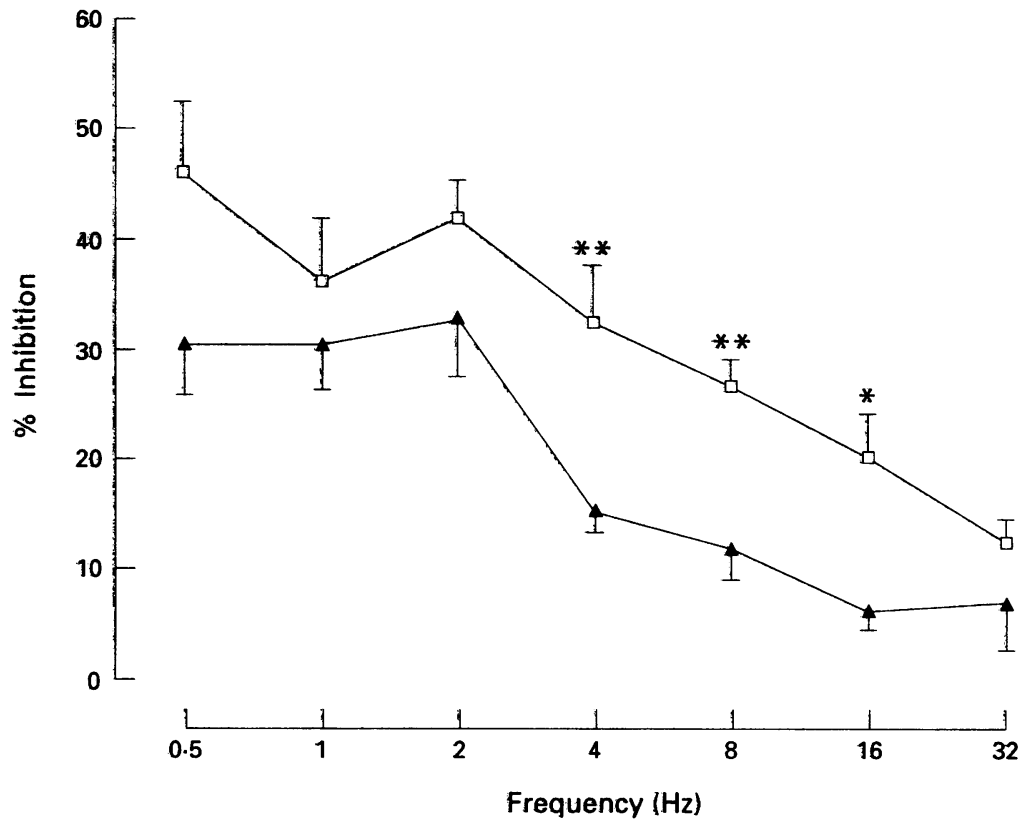

Figure 3 Inhibition of EFS-induced cholinergic contraction in epithelium-denuded tissues by frusemide (100 $\mu$ moll ll) in the presence ( $\Delta$ ) and absence ( $\square$ ) of indomethacin $(10 \mu \mathrm{mol} / \mathrm{l})$. Indomethacin attenuated the inhibitory effect of frusemide. Mean ( $S E$ ) values of five tissues are shoron. ${ }^{* *} p<0.01,{ }^{*} p<0.05$.

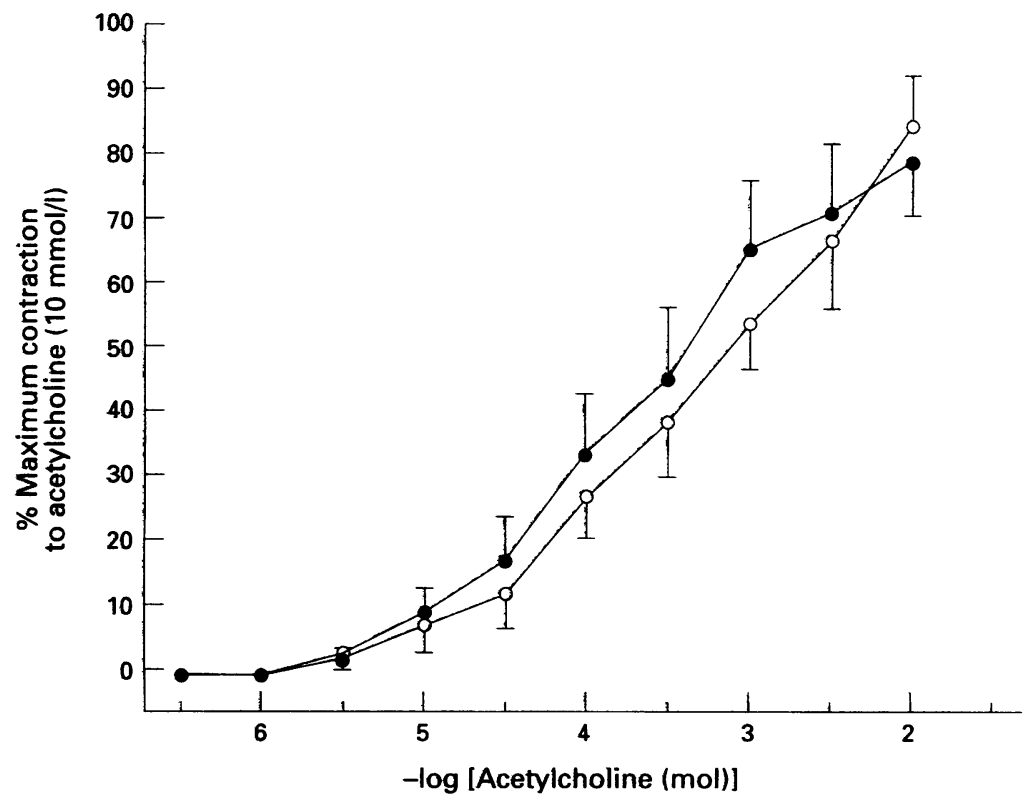
Figure 4 Cumulative concentration-response curve to exogenous acetylcholine
$(0.3 \mu \mathrm{moll}$ to 10 mmolll) in the presence $(\Theta)$ and absence $(O)$ of frusemide $(1$ molll). Mean (SE) values of five different epithelium-denuded tissues are shown.

\section{Discussion}

These results show that the loop diuretics frusemide and bumetanide inhibit the cholinergic contractions in response to EFS in human airways in vitro in a concentration dependent manner. Removal of the epithelium was necessary to achieve this effect. Neither diuretic, however, affected the cumulative concentration-response relationship to exogenous Ach, suggesting that they may act through a prejunctional mechanism. When indomethacin was omitted from the organ bath inhibition of the cholinergic contraction induced by frusemide, but not by bumetanide, was enhanced, although not significantly at all frequencies. This suggests that cyclooxygenase products may be involved in the mechanism of action of frusemide. Acetazolamide, a carbonic anhydrase inhibitor, produced no inhibition of the cholinergic contraction.

The mechanism of action of frusemide is not fully understood. In our experiments both frusemide and bumetanide inhibited the cholinergic contraction to EFS, so inhibition of the $\mathrm{Na}-\mathrm{K}-\mathrm{Cl}$ cotransportor, which is one of the mechanisms of action of loop diuretics in the kidney, ${ }^{19}$ cannot be excluded. Moreover, bumetanide was found to be about 10 times more potent than frusemide, as has been shown in previous in vitro studies. ${ }^{1320}$ In in vivo challenges bumetanide has little or no effect. $^{3}$ The same is true for piretanide and toresamide which are more potent diuretics but have less protective effect than frusemide in bronchoconstrictor challenges in asthmatic patients. ${ }^{21}$ Some investigators therefore question whether the inhibition of the $\mathrm{Na}-\mathrm{K}-\mathrm{Cl}$ contransporter is a possible explanation for the anti-asthmatic effects of frusemide. ${ }^{10}$ However, our results in human airways in vitro indicate that this effect certainly can not be dismissed, and the discrepancy between in vivo and in vitro results remains difficult to interpret. It has been postulated that local pharmacokinetic effects in the airways in vivo might explain this discrepancy and, in fact, frusemide, but not bumetanide, has been shown to produce an acute elevation of plasma renin, and an increased peripheral blood flow, ${ }^{22}$ which could account for an increased washout of exogenously administered bronchoconstrictor agents. Moreover, bumetanide, in contrast to frusemide, is highly lipid soluble, suggesting that bumetanide is not maintained in a high enough concentration at its site of action in the airways in vivo. ${ }^{23}$

Another explanation for the different effects of frusemide and bumetanide in vivo could be the fact that frusemide also possesses an inhibitory effect on carbonic anhydrase activity which bumetanide does not share, and that frusemide exerts its effect through inhibition of this enzyme. ${ }^{3}$ Our experiments, however, failed to demonstrate an inhibitory effect of acetazolamide on the EFS-induced cholinergic contraction, which makes this possibility unlikely. Moreover, carbonic anhydrase inhibition is unimportant in vitro as bumetanide, which has no such activity, was more effective than frusemide in our experiments.

Loop diuretics have an effect on airway nerves seen in guinea pig bronchi ${ }^{1324}$ and trachea $^{20}$ in vitro. Frusemide also has an inhibitory effect on various inflammatory cells, and the latter mechanism is probably important in some challenges in asthmatic patients. Frusemide inhibits the release of histamine and leukotrienes in passively sensitised human lung in vitro ${ }^{25}$ and in actively sensitised guinea pig lung. ${ }^{26}$ It also inhibits mediator release from eosinophils in vitro ${ }^{27}$ by inhibition of chloride transport. From these findings it has been suggested that frusemide exerts its effects through inhibition of a specific chloride channel. ${ }^{10}$ This seems an attractive hypothesis as 


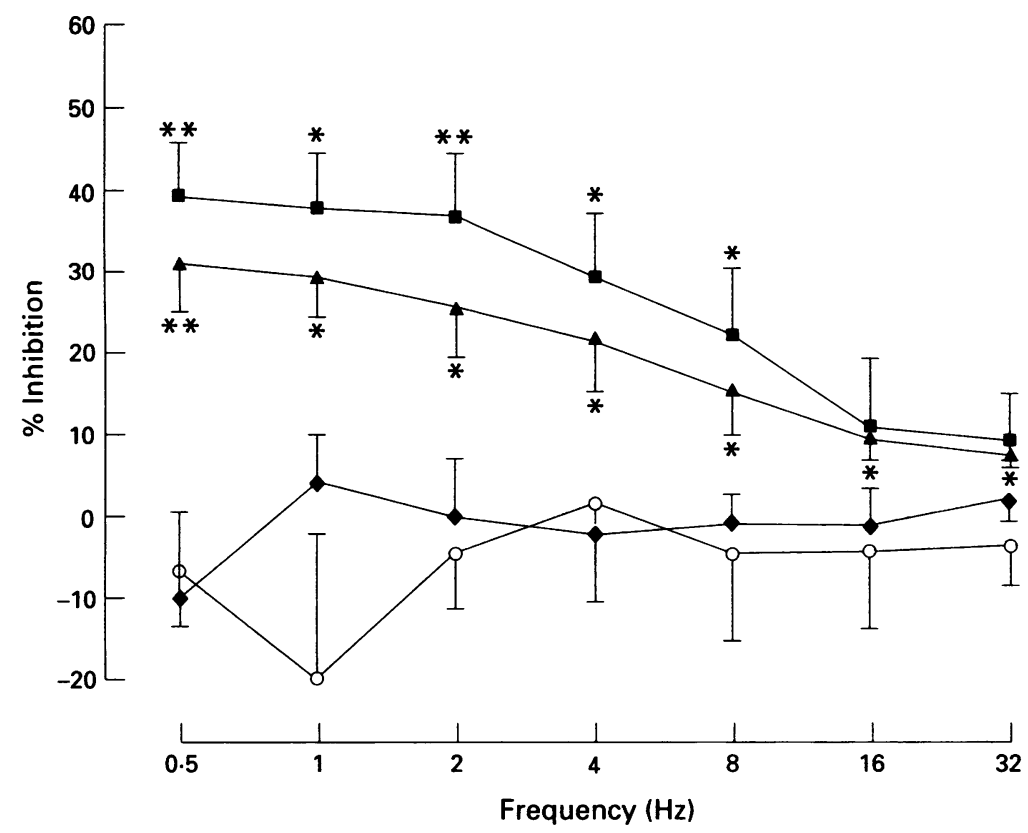

Figure 5 Inhibitory effect of different concentrations of bumetanide on the EFS-induced cholinergic contractions in human epithelium-denuded airways in the presence of indomethacin $(10 \mu \mathrm{mol} / \mathrm{l}): \Delta, 1 \mu \mathrm{mol} / \mathrm{l}$ bumetanide; $\Delta, 10 \mu \mathrm{mol} / \mathrm{l}$ bumetanide;, $100 \mu \mathrm{mol} / \mathrm{l}$ bumetanide. The bumetanide vehicle ( $\boldsymbol{\Delta}$ ) had no effect on the cholinergic contractions. Mean (SE) values of five different tissues are shown. $* * 0<01,{ }^{*} p<0.05$.

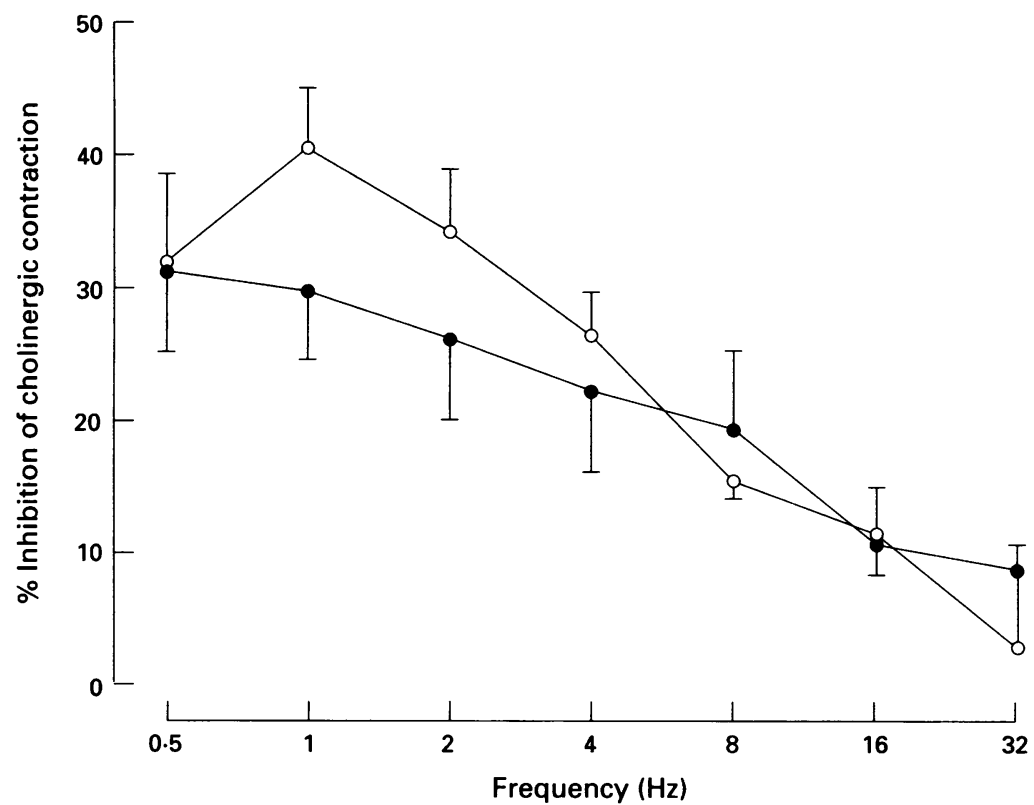

Figure 6 Inhibition of the EFS-induced cholinergic contraction in epitheliumdenuded tissues by bumetanide $(10 \mu \mathrm{mol} / \mathrm{l})$ in the presence $(O)$ and absence (O) of indomethacin $(10 \mu \mathrm{mol} / \mathrm{l})$. Indomethacin withdrawal did not result in an increased inhibitory effect of bumetanide. Mean (SE) of five tissues are shown.

nedocromil sodium possesses an inhibitory effect on chloride transport, ${ }^{28} 29$ but whether chloride channel blockers can inhibit cholinergic contraction in human airways in vitro remains to be investigated.

Frusemide enhances the synthesis of prostaglandin $E_{2}$ in the kidney and it has therefore been postulated that prostaglandin release may be involved in the protective effects of frusemide. Indeed, prostaglandins $E_{1}$ and $E_{2}$ have been shown to modulate airway neurotransmission. ${ }^{17}{ }^{30}$ Recent data provide evidence that inhibitory prostaglandins are involved in the prevention of exercise-induced asthma by frusemide. Indomethacin $(50 \mathrm{mg}$ three times daily) attenuated the protective effect of frusemide on exercise-induced asthma, ${ }^{31}$ and flurbiprofen, another cyclooxygenase inhibitor, did not modulate the protective effect of frusemide on metabisulphite-induced bronchoconstriction. This is either evidence against the release of inhibitory prostaglandins by frusemide, ${ }^{32}$ or for the release of prostaglandins by frusemide under certain conditions such as exerciseinduced asthma or other mast cell degranulating stimuli. Others have also failed to show increased production of prostaglandin $E_{2}$ in human nasal mucosa in vivo after frusemide instillation. ${ }^{33}$ In our experiments the frusemide-induced inhibition of the cholinergic contraction was enhanced when indomethacin was omitted from the organ bath, although this enhancement was only seen with a high dose $(100 \mu \mathrm{mol} / 1)$. The bumetanide-induced inhibition was, however, not enhanced when indomethacin was omitted from the organ bath, perhaps because it has no inhibitory effect on 15-hydroxyprostaglandin dehydrogenase, an enzyme involved in the inactivation of prostaglandins. ${ }^{34}$ Indomethacin in a concentration of $10 \mu \mathrm{mol} / 1$ augments the responsiveness of unrubbed canine bronchial rings to acetylcholine, which may be due to inhibition of the generation of prostaglandins. ${ }^{35}$ These results suggest that the release of prostaglandins may be involved in the inhibition induced by frusemide, but not by bumetanide, although this effect may not be important. Other in vitro experiments also suggest an influence of inhibitory prostaglandins. ${ }^{36}$

In our experiments loop diuretics only produced inhibition of the cholinergic contractions in tissues without epithelium and it seems unlikely that these inhibitory prostanoids are released by the epithelium. The site of prostaglandin release therefore remains speculative.

Frusemide failed to produce an inhibitory effect on cholinergic contractions in equine tracheal tisue without epithelium, suggesting that it produces its effects in this species through release of an epithelium-dependent relaxant factor. ${ }^{14}$ This is in agreement with the effect of frusemide on vascular smooth muscle where the vasoconstrictor response to periarterial electrical stimulation in rat tail artery with intact endothelium was inhibited, but this effect was absent in endothelium-denuded preparations. ${ }^{37}$ This contrasts with the findings of the previous studies - for example, Elwood $e t a l^{13}$ showed that frusemide modulated the cholinergic and non-cholinergic contractions in guinea pig airways by a prejunctional mechanism which was independent of the epithelium. In the present study, however, epithelium removal was necessary to achieve an inhibition of the cholinergic contraction by frusemide and bumetanide.

Mechanical removal of the epithelium enhances the responsiveness and sensitivity to 


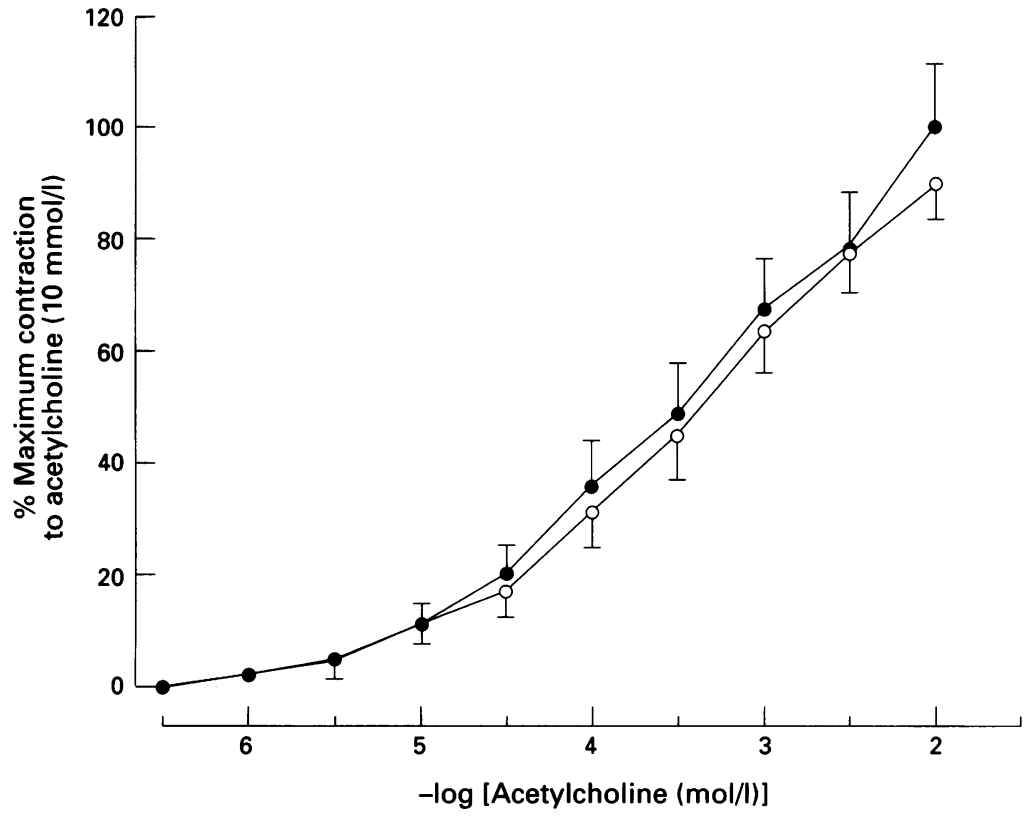

Figure 7 Cumulative concentration-response curve to exogenous acetylcholine $(0.3 \mu \mathrm{mol} / \mathrm{l}$ to $10 \mathrm{mmol} / \mathrm{l})$ in epithelium-denuded tissues in the presence ( $)$ and absence (O) of bumetanide $(100 \mu \mathrm{mol} / \mathrm{l})$. Mean (SE) values of eight tissues are shown.

several spasmogens in airway preparations from several animal species including man. ${ }^{38}$ This increased reactivity may be due to the existence of an inhibitory signal generated by the epithelium. ${ }^{35}$ The loss of an inhibitory factor cannot explain the inhibitory effect of loop diuretics in epithelium-denuded human airways in vitro.

Epithelium removal results in loss of a barrier function..$^{39} \mathrm{~A}$ direct inhibitory effect of frusemide on the smooth muscle is unlikely, however, as it has no effect on smooth muscle contractions induced by various constrictor agents. ${ }^{15}$ This was also seen in the present study as frusemide did not affect the doseresponse curve to exogenous Ach.

Epithelium removal also exposes airway nerves, a state similar to the airways of asthmatic subjects, where chronic inflammation causes damage to the epithelium, exposing sensory nerve endings. ${ }^{401}$ By removing the epithelium and exposing airway nerves frusemide could readily reach the nerves to exert its inhibitory effect. As high concentrations of frusemide are needed to inhibit the cholinergic contraction, however, a possible toxic effect of the loop diuretics on the airway nerves cannot be excluded.

This study has shown that loop diuretics, in a concentration-dependent manner, inhibit the cholinergic contraction in human airways in vitro by a prejunctional mechanism, but only in epithelium-denuded tissues. Cyclooxygenase products enhance this inhibitory effect with frusemide, whilst a carbonic anhydrase inhibitor has no inhibitory effect at all. Our experiments suggest that inhibition of $\mathrm{Na}-\mathrm{K}$ $\mathrm{Cl}$ cotransporter may explain the inhibitory effect of loop diuretics on cholinergic contraction. However, there is no explanation as to why epithelium removal is necessary to achieve this effect in human airways in vitro.

JLP is funded by Allen-Glaxo (Belgium).
1 Bianco S, Vaghi A, Robuschi M, Pasargiklian M. Prevention of exercise-induced bronchoconstriction by inhaled tion of exercise-induced bronchocon

2 Bianco S, Pieroni MG, Refini RM, Rottoli L, Sestoli P. Protective effect of inhaled furosemide on allergenProtective effect of inhaled furosemide on allergen-
induced early and late asthmatic reaction. $N$ Engl $\mathcal{F} \mathrm{Med}$ induced early and

3 O'Connor BJ, Chung KF, Chen-Worsdel YM, Fuller RW, Barnes PJ. Effect of inhaled furosemide and bumetanide on adenosine 5 -monophosphate and sodium metabisulfite-induced bronchoconstriction in asthmatic subjects. Am Rev Respir Dis 1991;143:1329-33.

4 Robuschi M, Gamboro G, Spagnotto S, Vaghi A, Bianco S. Inhaled furosemide is highly effective in preventing ultrasonically nebulised water bronchoconstriction. Pulm Pharmacol 1989;1:187-91.

5 Polosa R, Lau LC, Holgate ST. Inhibition of adenosine 5'monophosphate- and methacholine-induced bronchoconstriction in asthma by inhaled furosemide. Eur Respir $\mathcal{F}$ 1990;3:665-72.

6 Rodwell LG, Anderson SD, du Toit JI, Seale JP. The effect of inhaled frusemide on airway sensitivity to inhaled $4.5 \%$ sodium chloride aerosol in asthmatic subjects. Thorax 1993;48:208-13.

7 Nichol GM, Alton EWFW, Nix A, Geddes DM, Chung $\mathrm{KF}$, Barnes PJ. Effect of inhaled furosemide on metabisulfite and methacholine induced bronchoconstriction and nasal potential difference in asthmatic subjects. $\mathrm{Am}$ Rev Respir Dis 1990;142:576-80.

8 Grubbe RE, Hopp R, Dave NK, Brennan B, Bewtra A, Townley R. Effect of inhaled furosemide on the bronchial response to methacholine and cold-air hyperventilation response to methacholine and cold-air hypervent

9 Stone RA, Yeo TC, Barnes PJ, Chung KF. Frusemide inhibits cough but not bronchoconstriction to prostaglandin $\mathrm{F}_{2 x}$ in patients with asthma (abstract). Am Rev Respir Dis 1991;143:A548.

10 Barnes PJ. Diuretics and asthma. Thorax 1993;48:195-6.

1 Chung KF, Barnes PJ. Loop diuretics and asthma. Pulm Pharmacol 1992;5:1-7.

12 Bianco S, Pieroni MG, Refini RM, Robuschni M, Vaghi A, Sestini P. Inhaled loop diuretics as potetial new antiasthmatic drugs. Eur Respir f 1993;6:130-4.

13 Elwood WE, Lotvall JO, Barnes PJ, Chung KF. Loop diuretics inhibit cholinergic and noncholinergic nerves in guinea pig airways. Am Rev Respir Dis 1991:143:1340-4.

14 Yu M, Wang Z, Robinson NE, Derksen FJ. The inhibitory effect of furosemide on the contractile response of equine trachealis to cholinergic nerve stimulation. Pulm Pharmacol 1992;5: 233-8.

15 Knox AJ, Ajao P. Effect of furosemide on airway smooth muscle contractility in vitro. Thorax 1990;45:856-9.

16 Ward AB, Heel RC. Bumetanide: a review of its pharmacodynamic and pharmacokinetic properties and therapeutic use. Drugs 1984;28:426-64.

7 Ito $Y$. Prejunctional control of excitatory neuroeffector transmission by prostaglandins in the airway smooth muscle tissue. Am Rev Respir Dis 1992;143:S6-S10.

18 Belvisi MG, Stretton CD, Verleden GM, Ledingham SJL, Yacoub MH, Barnes PJ. Inhibition of cholinergic neurotransmission in human airways by opioids. $\mathcal{f}$ A ppl Physiol 1992;72:1096-100.

19 O'Grady SM, Palfrey HC, Field M. Na-K-2Cl cotransport in winter flounder intestine and bovine kidney outer medulla; ${ }^{3}[\mathrm{H}]$ bumetanide binding and effects of furomedulla; $[\mathrm{H}]$ bumetanide binding and effect

20 Verleden GM, Pype JL, Demedts MG. The effect of furosemide on non-adrenergic relaxation in guinea-pig furosemide on non-adrenergic relaxation in guinea-pig

21 Foresti A, Pelucchi A, Mastropasqua B, Cavigioli G, Earlesi RM, Marazzini L. Effect of inhaled furosemide and toresamide on bronchial responses to ultrasonically nebulized distilled water in asthmatic subjects. Am Rev Respir Dis 1992;146:364-8.

22 Passmore AP, Whitehead EM, Johnston GD. Comparison of the acute renal and peripheral vascular responses to frusemide and bumetanide at flow and high dose. $\mathrm{Br} f$ Clin Pharmacol 1989;27:305-12.

23 Lant A. Diuretics: clinical pharmacology and therapeutic use. Drugs 1985;29:57-87.

24 Mapp CE, Boniotti A, Papi A, Maggi CA, Di Stefano A, Saetta M, Ciaccia A, Fabbri LA. Effect of bumetanide on toluene diisocyanate induced contractions in guinea-pig airways. Thorax 1993;48:63-7.

25 Anderson SD, Wei HE, Temple DM. Inhibition by furosemide of inflammatory mediators from lung fragments. semide of inflammatory medic

26 Berti F, Rossoni G, Zuccari G, Buschi A, Robuschi M, Villa $\mathrm{LM}$, et al. Protective activity of inhaled furosemide against immunological respiratory changes and mediator release in guinea-pigs. Pulm Pharmacol 1992;5:115-20.

27 Perkins R, Dent G, Chung KF, Barnes PJ. Effect of anion transport inhibitors and extracellular $\mathrm{Cl}$-concentrations on eosinophil respiratory burst activity. Biochem Pharmacol 1992;107:481-8.

28 Jackson DM, Pollard CE, Roberts SM. The effect of nedocromil sodium on the isolated rabbit vagus nerve. Eur F Pharmacol 1992;221:175-8.

29 Reinsprecht M, Pecht I, Schindler H, Romanin C. Potent block of $\mathrm{Cl}$-channels by antiallergic drugs. Biochem Biophys Res Commun 1992;188:957-63.

30 Aikawa T, Sekizawa K, Itabashi S, Sasaki H, Takashima T Inhibitory action of prostaglandin $\mathrm{E}_{1}$ on non-adrenergic, non-cholinergic contraction in guinea-pig bronchus. $\mathrm{Br} \mathcal{f}$ Pharmacol 1990;101:13-4.

31 Pavord ID, Wisniewski A, Tattersfield AE. Inhaled fru- 
semide and exercise induced asthma: evidence of a role for inhibitory prostanoids. Thorax 1992;47:797-800.

32 O'Connor BJ, Barnes PJ, Chung KF. Inhibition of sodium metabisulphite induced bronchoconstriction by frusemide in asthma: role of cyclooxygenase products. Thorax 1994;49:307-11.

33 Mullol J, Ramis J, Prat J, Rosello-Catafour J, Xaubet A, Piera C, et al. Failure of furosemide to increase production of prostaglandin $\mathrm{E}_{2}$ in human nasal mucosa in vivo. Thorax 1993;48:260-3.

34 Stone KJ, Hart M. Inhibition of renal PGE -9 ketoreductase by diuretics. Prostaglandins 1976;12:197-207.

35 Flavahan NA, Aarhus LL, Rimele TJ, Vanhoutte PM. Respiratory epithelium inhibits bronchial smooth muscle Respiratory epithelium inhibits bron
tone. $\mathcal{A}$ Appl Physiol 1985;58:834-8.

36 Molimard M, Advenier C. Effect of furosemide on bradykinin- and capsaicin-induced contraction of the guineapig trachea. Eur Respir $\mathcal{f}$ 1993;6:434-9.
37 Gerkens JF. Inhibitory effect of furosemide on sympathetic vasoconstrictor responses: dependence on a renal hormone and the vascular endothelium. Clin Exp Pharmacol Physiol 1987;14:371-7.

38 Vanhoutte PM. Epithelium-derived relaxing factor(s) and bronchial reactivity. Am Rev Respir Dis 1988; 138:S24-S30.

39 Holroyde MC. The influence of epithelium on the responsiveness of guinea-pig isolated trachea. Br 7 Pharmacol 1986;87:501-7.

40 Laitinen A. Ultrastructural organisation of intraepithelial nerves in the human airway tract. Thorax 1985; 40:488-92.

41 Laitinen LA, Heino $M$, Laitinen A, Kava T, Haahtela T. Damage of the airway epithelium and bronchial reactivity in patients with asthma. Am Rev Respir Dis 1985; 131:599-906.

\section{Adventitia}

\section{A Philadelphia summer}

"The August heat was merciless. From the seventh to the twenty-seventh there were only two cool days. Twice there was rain and afterwards the sun shone through a steamy mist. Those who have lived through Philadelphia summers know these afternoons and would view with compassion the moist faces of the delegates". Thus wrote William Johnson, a Connecticut delegate to the Constitutional Convention which followed the Declaration of Independence two centuries ago.

Things were much the same in August 1976. The sweltering city of the founding fathers was again host to a great variety of groups celebrating the bicentenary of independence. There were conventions of magicians and candlemakers, a Eucharistic congress, national archery and rowing championships - and the fall meeting of the American Physiological Society to which I was to present a paper.

We had one great advantage over the perspiring delegates of 200 years ago - air conditioning - or did we? The first hint that something was amiss was when they switched off the air conditioning at my hotel. I was assured that this was a routine servicing procedure but why in the middle of an August heat wave and who were those heavies snooping around the lobby and corridors? And then the story broke with screaming headlines in the Philadelphia Daily News: dozens of delegates to the convention of the Pennsylvania branch of the American Legion, held in the city two weeks earlier, were being smitten by a mysterious disease from which 19 had already died. Hotel bookings were cancelled and the city, which had invested billions of dollars in the bicentennial celebrations, was facing bankruptcy. Rumours abounded. The veterans of foreign wars accused drug companies of conspiring to release a fatal flu virus in order to promote their vaccine sales. High levels of nickel had been found in the bodies of fatal cases and a left wing group (perhaps communist sailors from a Polish ship moored in the Delaware river) were thought to have injected nickel carbonyl gas into the air conditioning systems of hotels where the legionnaires were staying. Or was there some noxious element in the droppings of those rabbits and doves conjured out of hats at the magicians' convention?

These rumours were not confined to the tabloids and taverns of Philadelphia. Even the Lancet, as late as June 1977, was still promoting the nickel theory and contemplating the possibility that "careless chemists," "mad scientists," "saboteurs," or "criminals" were responsible; or perhaps the nickel carbonyl gas was coming from the garbage cans in which Philadelphians were burning their rubbish because of a garbage collectors' strike? And so the theories proliferated until Joseph McDate noticed a curious red patch on a culture from a guinea pig inoculated with lung tissue from a dead legionnaire. From this he grew Legionella pneumophila, the Gram negative bacillus now known to be the cause of the outbreak.

Of 182 patients with legionella pneumonia, 29 died. The victims included 149 legionnaires, nine Eucharists, two candlemakers, and one magician - but no physiologists. The majority of these had - as indeed had I entered the Bellevue-Stratford hotel or strolled along the adjacent sidewalk on Broad Street. Raised serum titres among the hotel employees suggested long term exposure to the bacillus and a degree of immunity, for only one of the 400 employees contracted the disease. This solitary case was the air conditioner man. Perhaps, like our famous predecessors two centuries ago, we too should have sweated out that Philadelphia summer and eschewed the comforts of modern technology. 